\title{
The Quality of Human Resources, Motivation and Leadership on the Performance of the Forensic Checker in the Peslabfor Bareskrim Indonesia Police
}

\author{
Meita Pragiwani*, Dewi Arni \\ Department of Management \\ Sekolah Tinggi Ekonomi Indonesia \\ Jakarta, Indonesia \\ *meita_pragiwani@stei.ac.id
}

\author{
Mohammad Benny Alexandri \\ Department of Management \\ Universitas Padjadjaran \\ Bandung, Indonesia \\ bennyalexandri@yahoo.co.id
}

\begin{abstract}
This study aims to analyze the performance of the forensic examiner in the Puslabfor Bareskrim Indonesia Police (POLRI) by looking at the factors of quality of human resources, motivation and leadership partially or simultaneously and the variables that have a large influence in this study. The methodology used in this study is multiple regression analysis and the sample used is $\mathbf{7 8}$ employees. The results of this study are variables of quality of human resources, motivation and leadership have an influence on the performance of forensic examiners Puslabfor Bareskrim POLRI is $\mathbf{9 6 . 4 \%}$.
\end{abstract}

Keywords: quality of human resources, motivation, leadership, performance

\section{INTRODUCTION}

The object of this research is the Forensic Examiner of the National Police Criminal Investigation Center. Along with government policies in terms of service to the community, the National Police Criminal Investigation Center which has the main task as supporting the investigation process carried out by investigators, the Puslabfor must be able to provide satisfaction to the customer / investigator in terms of providing results of examination of evidence in a criminal laboratory which can be accounted for in the court.

It is interesting to study because the Police Criminal Investigation Center has a very difficult task and is accompanied by the expectations of the leadership, especially the National Police Chief, so that the Police Criminal Investigation Center can fulfill all the investigators' desires in investigating criminal acts.

From absenteeism data it can be seen that the number of absentee examiners at the National Police Criminal Investigation Center, there are some examiners who do not come to work without information and some are on work leave. The existence of fluctuations in the increase and decrease in the percentage of absenteeism, in certain months the percentage of absenteeism / absenteeism is above 50\%. This shows that the level of attendance is quite high and not to mention the addition of employees who are late working. The following are employee absences in 2017.

TABLE I.

ABSENCE OF FoRENSIC EXAMINERS AT THE NATIONAL POLICE'S CRIMINAL INVESTIGATION CENTER IN 2017

\begin{tabular}{|c|c|c|c|c|c|}
\hline No & MONTHS & $\begin{array}{c}\text { TOTALEXAMI } \\
\text { NATION }\end{array}$ & $\begin{array}{c}\text { INVESTIGATO } \\
\text { RS ENTER }\end{array}$ & $\begin{array}{c}\text { INSPACTION } \\
\text { OF ABSEN }\end{array}$ & $\begin{array}{c}\text { PRESENTEAGE } \\
\text { ATTENDANCE }\end{array}$ \\
\hline 1 & January & 78 & 40 & 38 & 51 \\
\hline 2 & February & 78 & 41 & 37 & 52 \\
\hline 3 & March & 78 & 38 & 40 & 49 \\
\hline 4 & April & 78 & 38 & 40 & 49 \\
\hline 5 & May & 78 & 38 & 40 & 49 \\
\hline 6 & June & 78 & 31 & 47 & 40 \\
\hline 7 & July & 78 & 43 & 35 & 55 \\
\hline 9 & September & 78 & 36 & 42 & 47 \\
\hline 10 & October & 78 & 40 & 38 & 51 \\
\hline 11 & November & 78 & 39 & 39 & 50 \\
\hline 12 & December & 78 & 36 & 42 & 46 \\
\hline
\end{tabular}

Source: URTU Puslabfor Bareskrim Polri, December 2017

From case data of the last 5 (five) years the results of examining evidence at the Criminal Investigation Center of the Police Force can be seen that the completed files have reached an average above $89 \%$, whereas if you look at the duties and functions of the Criminal Investigation Center the National Police then the completion of the inspection file should be 
- Use a reward management system to convey messages about what the organization believes is important and what is prepared to provide financial and non-financial rewards.

- Develop employee relations strategies that give preference to employees.

From the explanation above, it can be concluded that human resources are real physical potential or non-physical that can contribute to an organization so that it can realize the existence of the organization it manages in accordance with the ideals and goals to be achieved.

Quality of Human Resources in government and private organizations is absolutely necessary. Because, through the quality of existing human resources, the performance of educators in carrying out their duties will be better. That is, he will get quality work, finished on time and efficiently in the use of necessary resources. In other words, Quality of Human Resources Influences Performance.

\section{B. Effect of Work Motivation on Performance}

Motivation is a group of factors that exist within and outside oneself that drive to achieve the goals that have been determined by devoting all the power and potential that exists. So that giving encouragement as a form of motivation can increase employee morale so that it can achieve the desired results by management. The relationship of motivation and performance has a linear form in the sense that by providing good work motivation, employee morale will increase and work results will be optimal in accordance with established performance standards. Work passion as a form of motivation can be seen, among others, from the level of employee attendance, responsibility for work time that has been set.

\section{Influence of Leadership on Performance}

The success of an organization, both as a whole and various groups within a particular organization, is very dependent on the quality of leadership contained in the organization concerned. It might even be said that the quality of leadership contained in an organization plays a very dominant role in the success of the organization in the performance of its employees [2].

The extent of the influence of the quality of human resources, work motivation and leadership on the performance of the forensic examiner at the Police Criminal Investigation Center, then compiled a research framework as follows:

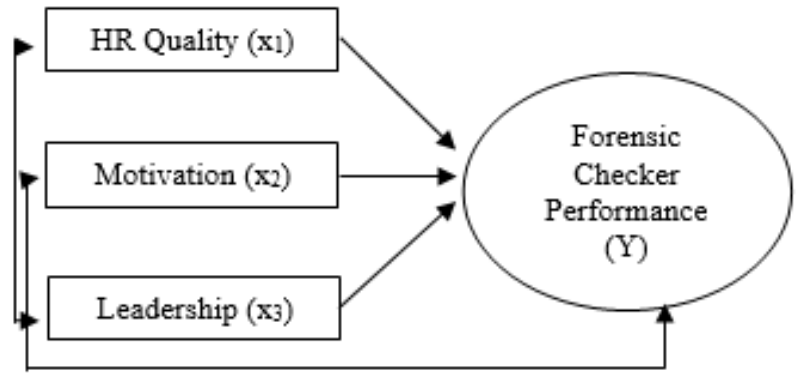

Fig. 1. Thinking framework. 
motivation and leadership that have an influence on the emergence of the dependent variable or the dependent variable, namely the performance of the forensic examiner of the Police Criminal Investigation Center.

The sample is a portion of the number and characteristics possessed by the population [3]. Based on the total population contained in the Police Criminal Investigation Center, the sample used is the population sample. The sampling technique in this study is to use techniques census. This technique is used because the population to be studied is less than 100 (one hundred) people, so the samples taken are from the entire population in the company of 78 (seventy-eight) people.

Multiple regression analysis is used to predict how the state (up and down) of the dependent variable, to the three independent variables as indicators. This analysis is used by involving two or more independent variables between the dependent variable (performance) and the independent variable (quality of human resources, motivation, and leadership).

\section{DISCUSSION}

The relationship between variables can clearly be described as a straight line. The independent variable or independent variable in this study is the quality of human resources,

TABLE III. DATA CASE OF INSPECTION OF EVIDENCE IN THE POLICE CRIMINAL INVESTIGATION CENTER

\begin{tabular}{|c|c|c|c|c|c|c|c|}
\hline \multirow{2}{*}{ Coefficients } & \multicolumn{2}{|c|}{ Unstandardized Coefficients } & \multirow{2}{*}{$\frac{\text { Coefficients Standardized }}{\text { Beta }}$} & \multirow{2}{*}{$\mathbf{T}$} & \multirow{2}{*}{ Sig } & \multicolumn{2}{|c|}{ Collinearity } \\
\hline & $\boldsymbol{B}$ & Std. Error & & & & Tolerance & VIF \\
\hline 1 (Constant & -.025 & ,106 & &,- 239 & 812 & & \\
\hline Quality of Power Source & 198 & & 005,183 & 3,581 & & 001,184 & 5,441 \\
\hline Motivation & & $1.092,06$ & 1.072 & 12.680, & & 000,067 & 14.890 \\
\hline Leadership & - & 315,074 &,- 280 & $-4,252$ & & 000,111 & 9.015 \\
\hline
\end{tabular}

According to the table 3, known regression constant value for -0.25 the regression coefficient variable quality of human resources (X1) of 0.198 , the regression coefficient motivation variable (X2) of 1.092, and the leadership variable regression coefficient (X3) of -0.315 . So the regression equation that is formed is as follows:

$$
\begin{aligned}
& \mathrm{Y}=\mathrm{a}+\mathrm{b} 1 \mathrm{X} 1+\mathrm{b} 2 \mathrm{X} 2+\mathrm{b} 3 \mathrm{X} 3+\mathrm{e} \\
& \mathrm{Y}=-0.25+0.198 \mathrm{X} 1+1,092 \mathrm{X} 2-0.315 \mathrm{X} 3+\mathrm{e}
\end{aligned}
$$

Equation The multiple regression can be explained as follows:

- Constants (a), this means that if all free variables have a value of zero (0) then the value of the dependent variable (Beta) of -0.25

- Quality of Human Resources (X1) to beta (Y)

- The value of the coefficient of Human Resources for variable $\mathrm{X} 1$ of 0.198 . This implies that each increase in the Quality of Human Resources one unit then the Beta variable (Y) will increase by 0.198 assuming that the other independent variables of the regression model are fixed.

- Motivation (X2) to beta (Y) The
- value of the motivation coefficient for the Xvariable is2 1.092 .

- This implies that each increase in motivation of one unit then the Beta (Y) variable will increase by 1.092 assuming that the other independent variables of the regression model are fixed.

- Leadership (X3) to beta (Y) The

- value of the price coefficient for variable $\mathrm{X} 3$ is -0.315

- This means that each increase in the price of one unit then the variable Beta (Y) will increase by -0.315 assuming that the other independent variables of the model regression is fixed.

- The coefficient of determination measures how far the model's ability to explain the variation of the dependent variable.

The following table is the coefficient of determination generated in the study:

TABLE IV. TEST R RODEL SUMMARY ${ }^{\mathrm{B}}$

\begin{tabular}{|l|c|c|c|c|}
\hline Model & R & R & $\begin{array}{c}\text { Adjusted } \\
\text { R Square }\end{array}$ & $\begin{array}{c}\text { Std. } \\
\text { Eror of } \\
\text { the estimasi }\end{array}$ \\
\hline 1 &, $982^{2}$ &, 964 &, 963 &, 07437 \\
\hline
\end{tabular}


According to the table 4 it can be seen that the value of R2 is 0.964 , this means that $96.4 \%$ of the variation in performance can be explained by variations of the three independent variables namely the quality of human resources, motivation and leadership, while the rest $(100 \%-96.4 \%=3.6 \%)$ is explained by other factors not examined.

\section{CONCLUSION}

\section{A. Conclusion}

Based on the results of research on the quality of human resources, motivation and leadership have an influence on the performance of the National Police Criminal Investigation forensic examiner, the conclusion is as follows:

- The variable quality of human resources significantly influences the performance of the National Police Criminal Investigation Police forensic examiner by $35.81 \%$.

- Motivational variables significantly influence the performance of the National Police Criminal Investigation Forensic examiner by $126.8 \%$.

- The leadership variable influences the performance of the National Police Criminal Investigation Forensic Investigator by $-42.52 \%$.

- The variable quality of human resources, motivation and leadership has an influence on the performance of the forensic examiner of the Police Criminal Investigation Body of $96.4 \%$ and the remaining $3.6 \%$ is influenced by other factors outside this research model.

\section{B. Suggestion}

Based on the results of the study and the limitations of the author, the following suggestions can be given:

- To improve the performance of the National Police Criminal Investigation forensic examiner, regular training must be held for members of the Police Criminal Investigation for the Police Criminal Investigation.
- Institutions should increase employee motivation because work motivation has a very high influence in improving the performance of forensic examiners.

- Leadership effectiveness is recommended for agencies to be further enhanced because it has a major effect on performance, especially related to decisions and policies as well as supervision as the results of respondents' answers. A good relationship that exists between leaders and employees can increase work motivation because employees feel noticed and valued so that employee performance increases as well.

- The performance of forensic examiners can be improved by changing the leadership style that militarism tends to be authoritarian to become humanist through the example given in the form of discipline, legal observance, morality, responsibility, cooperation, sensitivity to an issue, wise decision making so that it can be an example for subordinates in carrying out their duties so that the performance is expected to improve overall.

- Placing forensic examiners according to their scientific discipline so that they can support the examination and daily tasks so that the results of the official report can be accounted for.

A conducive working atmosphere among fellow members of the forensic examiner, good cooperation in carrying out daily tasks can improve the performance of the forensic examiner of the Police Criminal Investigation Center.

\section{REFERENCES}

[1] Sedarmayanti, Sumber Daya Manusia : ReformasiBirokrasi dan Manajemen Pegawai Negri Sipil. Bandung: Refika Aditama, 2017.

[2] S.P. Siagian, Manajemen Sumber Daya Manusia. Jakarta: Bumi Aksara, 2014

[3] Sugiyono, Metode Penelitian: Kuantitatif, Kualitatif Dan R\&D Vol.26. Bandung: Alfa Beta, 2017. 